\title{
Komunikasi Interpersonal dan Keterampilan Memberi Penguatan: Sebuah Analisa Korelasional terhadap Minat Belajar Siswa
}

\author{
Imroatul Mufidah $^{1}$ H. Asmawi ${ }^{2}$
}

\begin{abstract}
Abstrak: Belajar hendaknya menjadi prioritas untuk mencapai keberhasilan. Untuk mewujudkan kegiatan belajar sebagai prioritas, maka diperlukan minat yang tinggi. Salah satu upaya untuk meningkatkan minat belajar yaitu melalui komunikasi interpersonal dan keterampilan memberi penguatan. Oleh karena itu peneliti mencoba meneliti hubungan komunikasi interpersonal dan keterampilan memberi penguatan dengan minat belajar siswa. Penelitian ini menggunakan pendekatan kuantitatif (penelitian korelasi). Populasi dalam penelitian ini sejumlah 248 siswa kelas VII SMP Negeri 1 Pungging, dan sampel dalam penelitian ini sejumlah 50 siswa. Pengumpulan data dengan menggunakan instrumen angket, wawancara, dan dokumentasi. Ketiga instrumen tersebut digunakan untuk menggali data tentang: 1) komunikasi interpersonal, 2) keterampilan memberi penguatan, 3) minat belajar. Hasil dari penelitian ini menunjukkan: 1) Ada hubungan antara komunikasi interpersonal dengan minat belajar (2,091>2,011), 2) Ada hubungan antara keterampilan memberi penguatan dengan minat belajar $(3,289>2,011), 3)$ Ada hubungan antara komumikasi interpersonal dan keterampilan memberi penguatan dengan minat belajar $(6,787>3,20)$. Manfaat penelitian ini antara lain: 1) Bagi sekolah untuk menciptakan lingkungan yang dapat meningkatkan minat belajar siswa, 2) Bagi guru untuk memotivasi dalam meningkatkan minat belajar siswa, 3) Bagi siswa untuk meningkatkan kesadaran tentang pentingnya minat belajar.
\end{abstract}

Kata Kunci : Komunikasi Interpersonal, Keterampilan Memberi Penguatan, Minat Belajar

Secara historis, minat merupakan salah satu faktor pokok untuk meraih sukses dalam studi. ${ }^{3}$ Komunikasi merupakan dasar dari seluruh interaksi antar manusia. Dan pada kenyataannya dari berbagai macam komunikasi, komunikasi antar pribadi adalah komunikasi yang sangat berpengaruh dalam kehidupan sehari-hari. ${ }^{4}$ Komunikasi interpersonal adalah komunikasi antara orang-orang secara tatap muka, yang memungkinkan setiap pesertanya menangkap reaksi orang lain secara langsung, baik secara verbal atau nonverbal. ${ }^{5}$

\footnotetext{
${ }^{1}$ Imroatul Mufidah, Mahasiswa IAI Uluwiyah Mojokerto, Fakultas Tarbiyah.

${ }^{2}$ H. Asmawi, Dosen Pembimbing I IAI Uluwiyah Mojokerto.

${ }^{3}$ Makmun Khairani, Psikologi Belajar, (Yogyakarta: Aswaja Pressindo, 2013), 143.

${ }^{4}$ Suranto, Komunikasi Interpersonal, (Yogyakarta: Graha Ilmu, 2011), 2.

${ }^{5}$ Deddy Mulyana, Ilmu Komunikasi: Suatu Pengantar, (Bandung: Remaja Rosdakarya, 2000), 73. Palapa: Jurnal Studi Keislaman dan Ilmu Pendidikan 
Konsep diri dan persepsi interpersonal sangat dibutuhkan untuk pencapaian dalam kelancaran komunikasi. Orang yang lancar dalam berkomunikasi berarti orang tersebut mempunyai keahlian dalam berkomunikasi. Persepsi interpersonal besar pengaruhnya bukan saja pada komunikasi interpersonal, tetapi juga pada hubungan interpersonal. Karena itu kecermatan persepsi interpersonal akan sangat berguna untuk meningkatkan kualitas komunikasi interpersonal kita. ${ }^{6}$ Dengan ini sangat penting bagi guru untuk memiliki kemampuan komunikasi interpersonal yang baik agar tidak mengalami kesulitan dalam proses pembelajaran. Dan juga untuk menghindari dari kesalahan persepsi antara tujuan guru dalam mengajar atau memberikan informasi dengan informasi yang diterima oleh peserta didik.

Komunikasi interpersonal dinyatakan efektif bila pertemuan komunikasi merupakan hal yang menyenangkan bagi komunikan, sebagaimana yang sudah dibuktikan oleh Wolosin (1975) yang menyatakan bahwa komunikasi akan lebih efektif bila para komunikan saling menyukai. Lott dan Lott (1966) juga menemukan bahwa murid-murid belajar bahasa Spanyol lebih cepat bila bekerja sama dengan orang-orang yang mereka senangi. ${ }^{7}$

Dengan demikian jika guru mempunyai keahlian komunikasi interpersonal yang baik, maka komunikasi yang dilakukan dalam proses pembelajaran akan berjalan efektif. Dengan komunikasi yang baik itu akan melahirkan ketertarikan bagi peserta didik dalam menerima pelajaran. Sehingga peserta didik akan lebih senang dalam belajar dan fokus pada mata pelajaran yang sedang diajarkan, karena proses penyampaian informasi yang baik oleh guru dalam mengajar. Hal ini akan dapat meningkatkan minat siswa dalam belajar. Selain itu, komunikasi interpersonal merupakan faktor yang sangat penting dalam meningkatkan keterampilan mengajar guru terutama keterampilan memberi penguatan, karena dengan komunikasi interpersonal guru akan dapat memberikan penguatan baik berupa kata-kata atau kalimat yang tepat bagi siswanya.

Keterampilan dasar mengajar merupakan kemampuan yang bersifat khusus yang harus dimiliki tenaga pengajar agar dapat melaksanakan tugas mengajar secara

\footnotetext{
${ }^{6}$ Jalaluddin Rakhmat, Psikologi Komunikasi, (Bandung: Remaja Rosdakarya, 2012), 79.

${ }^{7}$ Ibid., 116.
} 
efektif, efisien, dan profesional. ${ }^{8}$ Keterampilan dasar mengajar bagi guru diperlukan agar guru dapat melaksanakan perannya dalam pengelolaan proses pembelajaran, sehingga pembelajaran dapat berjalan secara efektif dan efisien. Salah satu keterampilan dasar mengajar guru adalah keterampilan memberi penguatan. ${ }^{9}$

Keterampilan memberi penguatan merupakan keterampilan memberi respon positif dengan tujuan mempertahankan dan meningkatkan perilaku tertentu. ${ }^{10}$ Penguatan merupakan salah satu bentuk penciptaaan suasana belajar yang menyenangkan. Reinforcement diberikan pada siswa dengan tujuan utama agar frekuensi tingkah laku positif siswa dapat meningkat. Hal ini sesuai dengan teori belajar Skinner dalam Suryabrata yang menyatakan bahwa tingkah laku peserta didik dapat dikondisikan dengan memberikan penguatan (reinforcement). ${ }^{11}$ Berdasarkan uraian di atas, reinforcement dapat meningkatkan perilaku positif peserta didik. Salah satu perilaku positif tersebut adalah minat yang meningkat.

Jika kemampuan komunikasi interpersonal dipadukan dengan keterampilan guru memberi penguatan dalam kegiatan belajar mengajar, maka akan meningkatkan perhatian dan ketertarikan siswa serta keterlibatan siswa dalam belajar, yang mana semua itu merupakan pengukuran dari minat belajar. Maka dari itu di dalam pendidikan, komunikasi interpersonal dan keterampilan memberi penguatan guru Pendidikan Agama Islam mempunyai hubungan dengan minat belajar siswa.

Minat belajar adalah keterlibatan sepenuhnya seorang siswa dengan segenap kegiatan pikiran secara penuh perhatian untuk memperoleh pengetahuan dan mencapai pemahaman tentang pengetahuan ilmiah yang dituntutnya di sekolah. ${ }^{12}$ Lebih jauh lagi, menurut Prastyo kompetensi, dalam hal ini adalah pengetahuan siswa, merupakan salah satu tujuan yang harus dicapai dan dikuasai oleh siswa untuk memprsiapkan diri menghadapi dunia global. ${ }^{13}$

\footnotetext{
8 Didi Supriadie dan Deni Darmawan, Komunikasi Pembelajaran, (Bandung: PT. Remaja Rosdakarya, 2012), 154.

9 Zainal Aqib, Membangun Profesionalisme Guru Dan Pengawas Sekolah, (Bandung: Yrama Widya, 2007), 61.

${ }^{10}$ Barnawi dan M. Arifin, Micro Teaching, (Yogyakarta: Ar-Ruzz Media, 2015), 141.

${ }^{11}$ Sumadi Suryabrata, Metodologi Penelitian, (Jakarta: Rajawali Pres, 2010), 217.

12 Makmun Khairani, Op.Cit., 142.

13 Hari Prastyo, Pemberdayaan Pesantren: membangun Generasi Islami melalui Pembinaan Keterampilan Berbahasa Asing, Al-Murabbi: Jurnal Studi Kependidikan dan Keislaman,2017, 4(1),18.
}

3 Palapa: Jurnal Studi Keislaman dan Ilmu Pendidikan 
Suatu kegiatan yang dilakukan tidak sesuai dengan minat akan menghasilkan prestasi yang kurang menyenangkan. Dapat dikatakan bahwa dengan terpenuhinya minat seseorang akan mendapatkan kesenangan dan kepuasan batin yang dapat menimbulkan motivasi. Munandar menyatakan bahwa minat dapat juga menjadi kekuatan motivasi. Prestasi seseorang selalu dipengaruhi macam dan intensitas minatnya. ${ }^{14}$

Minat menimbulkan kepuasan. Seorang anak cenderung untuk mengulangulang tindakan-tindakan yang didasari oleh minat dan minat ini dapat bertahan selama hidupnya. Dengan demikian, minat belajar merupakan faktor yang sangat penting dalam keberhasilan belajar siswa. Di samping itu minat belajar juga dapat mendukung dan mempengaruhi proses belajar mengajar di sekolah. Namun dalam praktiknya tidak sedikit guru yang menemukan kendala dalam mengajar di kelas karena kurangnya minat siswa terhadap materi yang disampaikan. Jika hal ini terjadi, maka proses belajar mengajar akan mengalami hambatan dalam mencapai tujuan pembelajaran.

Dari kenyataan dan hasil pengamatan selama ini sering kali guru tidak mengganggap bahwa komunikasi interpersonal dan keterampilan memberi penguatan guru Pendidikan Agama Islam merupakan dukungan untuk meningkatkan minat belajar siswa. Maka perlu ditingkatkan kemampuan komunikasi interpersonal guru dan terus meningkatkan keterampilan memberi penguatan guru Pendidikan Agama Islam agar dapat meningkatkan minat belajar siswa.

Dalam penelitian terdahulu yang dilakukan oleh Ana Semi (2012) dari Universitas Islam Negeri Sultan Syarif Kasim Riau Pekanbaru dengan judul Hubungan Keterampilan Memberi Penguatan dengan Motivasi Belajar Siswa pada Mata Pelajaran Fiqih di MTs Hubbul Wathan Kuantan Singingi yang dalam pengumpulan data menggunakan metode observasi dan dokumentasi dan pada analisis data menggunakan deskriptif kuantitatif menunjukkan bahwa terdapat hubungan positif antara keterampilan guru dalam memberi penguatan dengan motivasi belajar siswa pada mata pelajaran Fiqih di MTs Hubbul Wathan berada pada kategori kuat, r (pearson correlation) sebesar 0,791, yakni pada rentang 0,60-0,799.

14 S. C. Utami Munandar, Mengembangkan Bakat dan Kreativitas Anak Sekolah: Petunjuk bagi Guru dan Orang Tua, (Jakarta: Gramedia Widiasarana Indonesia, 1985), 11. 
Dengan probabilitas 0,000 , lebih kecil dari 0,05 yang berarti $\mathrm{Ha}$ diterima dan Ho ditolak. Begitu juga dengan penelitian yang dilakukan oleh Fahrul Usman (2015) dari Universitas Islam Negeri Alauddin Makassar dengan judul Pengaruh Komunikasi Interpersonal Guru terhadap Minat Belajar pada Mata Pelajaran Matematika Siswa Kelas VII Di SMP Pesantren Immim Putra Makassar yang dalam pengumpulan data menggunakan metode kuesioner dan pada analisis data menggunakan deskriptif kuantitatif menunjukkan bahwa komunikasi interpersonal guru berpengaruh terhadap hasil minat belajar matematika pada siswa kelas VIII di SMP Pesantren IMMIM Putra Makassar dengan dibuktikan dari hasil perhitungan diperoleh $\mathrm{F}_{\text {hitung }}$ dengan harga signifikansi kurang dari 0,05. Variabel komunikasi interpersonal guru berpengaruh terhadap variabel minat belajar matematika sebesar $35 \%$.

Jadi perbedaan dari penelitian terdahulu dengan penelitian ini yaitu, pada penelitian yang dilakukan oleh Ana Semi dan Fahrul Usman menggunakan dua variabel sedangkan dalam penelitian ini menggunakan tiga variabel. Begitu juga dalam hal subjek penelitian, Ana Semi menggunakan siswa MTs Hubbul Wathan, dan Fahrul Usman menggunakan siswa kelas VII SMP Pesantren, sedangkan dalam penelitian ini menggunakan siswa kelas VII SMP Konvensional yaitu SMP Negeri 1 Pungging.

Oleh karena itu, berdasarkan latar belakang tersebut di atas, penulis tertarik untuk mengadakan penelitian tentang "Komunikasi Interpersonal dan Keterampilan Memberi Penguatan: Sebuah Analisa Korelasional terhadap Minat Belajar Siswa”.

\section{METODE}

Populasi dalam penelitian ini sejumlah 248 siswa kelas VII SMP Negeri 1 Pungging, dan sampel dalam penelitian ini sejumlah 50 siswa kelas VII SMP Negeri 1 Pungging. Dalam hal pengumpulan data tentang komunikasi interpersonal guru Pendidikan Agama Islam, keterampilan memberi penguatan guru Pendidikan Agama Islam, dan minat belajar Pendidikan Agama Islam siswa dikumpulkan melalui penyebaran angket, hasil wawancara dan dokumentasi. Teknik analisis yang dipakai dalam penelitian ini yaitu regresi berganda. Analisis regresi berganda adalah analisis tentang hubungan antara satu dependen variabel dengan dua atau lebih 
independen variabel. ${ }^{15}$ Jadi bila dihubungkan dengan penelitian ini maka analisis regresi berganda adalah untuk mengidentifikasi variabel-variabel yang mempengaruhi minat belajar Pendidikan Agama Islam siswa kelas VII SMP Negeri 1 Pungging. Dalam penelitian ini variabel-variabel yang mempengaruhi minat belajar Pendidikan Agama Islam adalah komunikasi interpersonal guru Pendidikan Agama Islam dan keterampilan memberi penguatan guru Pendidikan Agama Islam. Analisis dalam penelitian ini menggunakan program SPSS for Windows 16.0. ${ }^{16}$

Dalam hal rancangan penelitian yaitu dengan mencari hubungan komunikasi interpersonal guru Pendidikan Agama Islam dengan minat belajar Pendidikan Agama Islam $\left(\mathrm{r}_{1}\right)$, hubungan keterampilan memberi penguatan guru Pendidikan Agama Islam dengan minat belajar Pendidikan Agama Islam $\left(\mathrm{r}_{2}\right)$, hubungan komunikasi interpersonal guru Pendidikan Agama Islam dengan keterampilan memberi penguatan guru Pendidikan Agama Islam $\left(\mathrm{r}_{3}\right)$ yang kemudian keduanya secara bersama-sama dihubungkan dengan minat belajar Pendidikan Agama Islam (R).

\section{HASIL PENELITIAN}

\section{A. Hasil Analisis Data}

\section{Uji Normalitas}

Pengujian normalitas bertujuan untuk menguji asumsi bahwa distribusi sampel dari galat taksiran sampel berasal dari populasi yang berdistribusi normal. Ketentuan pengujian normalitas dengan memakai uji Kolmogorof-Smirnov dengan kriteria yaitu jika probabilitas atau asymp. Sig (2-tailed) lebih besar dari level of significant $(a=0,05)$, maka data berdistribusi normal. Berdasarkan uji normalitas dari hasil perhitungan SPSS dapat disimpulkan bahwa seluruh data sampel setiap variabel berdistribusi normal, karena probabilitas atau asymp. Sig (2-tailed) lebih besar dari level of significant $(a=0,05)$. Uji normalitas juga dapat dibuktikan dengan melihat nilai skewness dan p-p plots. Melihat gambar Normal P-P Plot of Regression standardized residual dari hasil analisis SPSS dapat disimpulkan bahwa data berdistribusi normal. Hal ini dapat dilihat dari gambar diagram pencar di mana titik-titik yang berada di sekitar garis lurus.

15 Akib Hamid, Statistika Dasar, (Jakarta: UT, 2009), 136.

${ }^{16}$ Ibid., 142. 


\section{Uji Linieritas}

Uji linieritas bertujuan untuk menguji linieritas hubungan antar variabel. Teknik pengujian linieritas yang dipakai dalam penelitian ini adalah uji linieritas dari ANOVA, dengan ketentuan $\mathrm{F}_{\text {bitung }}<\mathrm{F}_{\text {tabel }}$ dan jika nilai sig. deviasion from linierity lebih besar $(>)$ dari level of significant $(\alpha=0,05)$ maka hubungan bersifat linier. Sebagaimana hasil analisis SPSS dapat disimpulkan bahwa seluruh hubungan antar variabel bersifat linier. Hal ini dibuktikan dengan nilai $\mathrm{F}_{\text {bittug }}<\mathrm{F}_{\text {tabel }}(0,445<2,03 ; 1,040<2,01)$ dan nilai sig. deviasion from linierity $>$ level of significant $(\alpha=0,05)(0,933>0,05 ; 0,438>$ $0,05)$.

\section{Uji Multikolinearitas}

Multikolinearitas timbul akibat adanya hubungan kausal antara dua variabel bebas atau lebih atau adanya kenyataan bahwa dua atau lebih variabel penjelas bersama-sama dipengaruhi oleh variabel ketiga yang berada di luar model. Untuk mendeteksi adanya multikolinearitas bisa lihat nilai VIF (Variance Inflation Factor) berada di bawah 10, selain itu nilai Tolerance lebih dari 0,1, maka diambil kesimpulan bahwa tidak terjadi multikolinieritas. Dari perhitungan analisis data dengan SPSS dapat dilihat bahwa nilai VIF hubungan variabel $\mathrm{X}_{1}$ dan $\mathrm{X}_{2}$ berada di bawah 10 $\left(\mathrm{X}_{1}=1,050 \mathrm{X}_{2}=1,050\right)$, dan nilai Tolerance lebih dari 0,1 $\left(\mathrm{X}_{1}=0,953 \mathrm{X}_{2}=0,953\right)$. Dengan demikian menunjukkan tidak terjadi multikolinieritas.

\section{Uji Heteroskedastisitas}

Untuk mengetahui ada tidaknya heteroskedastisitas adalah dengan memperhatikan gambar Scatterplot. Dari gambar Scatterplot terlihat bahwa penyebaran titik-titik data tidak berpola, titik-titik data menyebar di atas atau di bawah atau di sekitar angka 0, dan titik-titik data tidak mengumpul hanya di atas atau hanya di bawah saja. Dengan demikian dapat disimpulkan bahwa data tidak terdapat heteroskedastisitas.

\section{Uji Autokorelasi}

Autokorelasi adalah korelasi yang terjadi di antara anggota observasi yang terletak berderetan. Untuk mendeteksi autokorelasi dapat dilakukan dengan uji Durbin Watson (DW) dengan ketentuan sebagai berikut:

a. 1,65<DW $<2,35$ maka tidak ada autokorelasi

b. $1,21<\mathrm{DW}<1,65$ atau $2,35<\mathrm{dw}<2,79$ maka tidak dapat disimpulkan

7 Palapa: Jurnal Studi Keislaman dan Ilmu Pendidikan 
c. $\mathrm{DW}<1,21$ atau $\mathrm{DW}>2,79$, maka terjadi autokorelasi

Melihat hasil analisis dari SPSS dapat diketahui bahwa nilai Durbin Watson sebesar 2,013. Karena nilai 2,013 berada dalam interval 1,65<DW $<2,35$, maka dapat disimpulkan tidak terjadi autokorelasi.

\section{B. Hasil Pengujian Hipotesis}

Pengujian hipotesis penelitian akan dilakukan untuk masing-masing hipotesis secara berturut-turut dengan melihat koefisien korelasi dan kekuatan hubungan, signifikansi koefisien korelasi, persamaan regresi yang terbentuk, koefisien determinasi dan arah hubungan sebagai berikut.

\section{Hubungan antara Komunikasi Interpersonal Guru Pendidikan Agama Islam dengan Minat Belajar Pendidikan Agama Islam}

Berdasarkan analisis data dengan bantuan program SPSS versi 16.0 for windows maka dapat dijelaskan bahwa nilai koefisien korelasi $\left(\mathrm{r}_{\mathrm{xy}}\right)$ antara komunikasi interpersonal dengan minat belajar adalah 0,289 dan $F_{\text {hitung }}\left(F_{\text {Change }}\right)=4,371$ dan $F_{\text {tabel }}$ $(2,47 ; 0,05)=3,20$ dengan $p$-value $=0,042<0,05$. Dengan demikian koefisien komunikasi interpersonal adalah signifikan. Adapun kriteria kekuatan pengaruh dapat dijelaskan dari $r_{\text {hitung }}(0,289)$ berkorelasi positif dengan derajat hubungan rendah. Hubungan tersebut baru berlaku untuk sampel sebesar 50 siswa. Untuk menguji apakah korelasi tersebut juga berlaku untuk populasi sebesar 248 siswa, maka perlu diuji signifikansi koefisien korelasi. Ketentuannya adalah terima $\mathrm{Ha}$ jika $t_{\text {hitung }}>t_{\text {tabel }}$ dan tolak Ha jika $t_{\text {hitung }}<t_{\text {tabel }}$.

Dari perhitungan analisis data dengan SPSS diketahui bahwa $t_{\text {hitung }}$ sebesar 2,091 sedangkan $t_{\text {tabel (0,05:47) }}$ adalah 2,011. Dengan demikian dapat dijelaskan bahwa $\mathrm{t}_{\text {hitung }}>\mathrm{t}_{\text {tabel }}(2,091>2,011)$ oleh karena itu Ha diterima. Ini berarti bahwa korelasi komunikasi interpersonal dengan minat belajar adalah berarti atau signifikan. Karena korelasi adalah positif, maka dapat dikatakan bahwa koefisien korelasi komunikasi interpersonal bersifat positif artinya makin tinggi komunikasi interpersonal makin tinggi pula minat belajar siswa yang dapat dilakukan.

Adapun persamaan regresi yang terbentuk dari analisis data dengan SPSS adalah: $\hat{Y}=81,247+0,279$. Dari persamaan regresi tersebut diketahui bahwa variabel bebas bertanda positif, ini berarti bahwa variabel bebas memiliki hubungan 
searah dengan variabel terikatnya. Artinya jika variabel komunikasi interpersonal $\left(\mathrm{X}_{1}\right)$ ditingkatkan satu satuan maka akan berdampak pada meningkatnya minat belajar sebesar 0,279 satuan. Sedangkan konstanta sebesar 81,247 menyatakan bahwa jika tidak ada hubungan variabel bebas $\left(\mathrm{X}_{1}\right)$ maka nilai komunikasi interpersonal adalah 81,247. Adapun besarnya koefisien determinasi ( $R$ Square) adalah 0,083. Ini artinya variabel komunikasi interpersonal memberikan konstribusi dengan minat belajar siswa sebesar $8,3 \%$ selebihnya $91,7 \%$ dipengaruhi variabel atau faktor lainnya yang belum diteliti.

\section{Hubungan antara Keterampilan Memberi Penguatan Guru Pendidikan Agama Islam dengan Minat Belajar Pendidikan Agama Islam}

Berdasarkan analisis program SPSS versi 16.0, maka hubungan keterampilan memberi penguatan dengan minat belajar dapat dijelaskan bahwa nilai koefisien korelasi $\left(\mathrm{r}_{\mathrm{xy}}\right)$ antara keterampilan memberi penguatan dengan minat belajar adalah 0,429 dan $\mathrm{F}_{\text {hitung }}\left(\mathrm{F}_{\text {Change }}\right)=10,817$ dan $\mathrm{F}_{\text {tabel }(2,47 ; 0,05)}=3,20$ dengan $p$-value $=0,002<$ 0,05. Dengan demikian koefisien korelasi ketrampilan memberi penguatan dengan minat belajar adalah signifikan. Kemudian dapat juga dijelaskan bahwa $r_{\text {hitung }}(0,429)$ berkorelasi positif dengan derajat hubungan agak rendah. Hubungan tersebut baru berlaku untuk sampel sebesar 50 siswa. Untuk menguji apakah korelasi tersebut juga berlaku untuk populasi sebesar 248 siswa, maka perlu diuji signifikansi koefisien korelasi. Ketentuannya adalah terima Ha jika $t_{\text {hitung }}>t_{\text {tabel }}$ dan tolak Ha jika $t_{\text {hitung }}<t_{\text {tabel }}$.

Dari perhitungan analisis data dengan SPSS diketahui bahwa $t_{\text {hitung }}$ sebesar 3,289 sedangkan $t_{\text {tabel }(0,05: 47)}$ adalah 2,011. Dengan demikian dapat dijelaskan bahwa $t_{\text {hitung }}>t_{\text {tabel }}(3,289>2,011)$ oleh karena itu Ha diterima. Ini berarti bahwa korelasi keterampilan memberi penguatan dengan minat belajar adalah signifikan. Karena korelasi adalah positif, maka dapat dikatakan bahwa koefisien korelasi keterampilan memberi penguatan dengan minat bersifat positif dan signifikan artinya makin tinggi keterampilan memberi penguatan makin tinggi pula minat belajar yang dapat dicapai.

Adapun persamaan regresi yang terbentuk dari analisis data dengan SPSS adalah: $\hat{Y}=75,848+0,435$. Dari persamaan regresi tersebut diketahui bahwa variabel bebas bertanda positif, ini berarti bahwa variabel bebas memiliki hubungan searah dengan variabel terikatnya. Artinya jika variabel keterampilan memberi penguatan $\left(\mathrm{X}_{2}\right)$ ditingkatkan satu satuan maka akan berdampak pada meningkatnya minat belajar

9 Palapa: Jurnal Studi Keislaman dan Ilmu Pendidikan 
0,435 satuan. Sedangkan konstanta sebesar 75,848 menyatakan bahwa jika tidak ada hubungan variabel bebas $\left(\mathrm{X}_{2}\right)$ maka minat belajar adalah 75,848 . Adapun besarnya koefisien determinasi ( $R$ Square) adalah 0,184. Ini artinya variabel keterampilan memberi penguatan memberikan konstribusi minat belajar sebesar 18,4\% selebihnya $81,6 \%$ berhungan dengan variabel atau faktor lainnya yang belum diteliti.

\section{Hubungan antara Komunikasi Interpersonal Guru Pendidikan Agama Islam dan Keterampilan Memberi Penguatan Guru Pendidikan Agama Islam dengan Minat Belajar Pendidikan Agama Islam}

Berdasarkan analisis data dengan bantuan program SPSS versi 16.0 for windows, korelasi komunikasi interpersonal dan keterampilan memberi penguatan adalah 0,129 $>0,05$ yang berarti tidak terdapat korelasi yang signifikan. Dengan demikian korelasi antara komunikasi interpersonal dengan keterampilan memberi penguatan adalah tidak signifikan. Sedangkan berdasarkan hasil analisis data hubungan komunikasi interpersonal dan keterampilan memberi penguatan dengan minat belajar dengan program SPSS dapat menghasilkan persamaan regresi sebagai berikut:

$$
\hat{Y}=63,549+0,198+0,390
$$

Dari persamaan tersebut dapat dijelaskan bahwa koefisien regresi linier berganda dari kedua variabel bebas bertanda positif, ini memiliki arti bahwa kedua variabel bebas tersebut $\left(\mathrm{X}_{1}\right.$ dan $\left.\mathrm{X}_{2}\right)$ memiliki hubungan searah dengan variabel terikatnya. Artinya jika variabel komunikasi interpersonal $\left(\mathrm{X}_{1}\right)$ ditingkatkan satu satuan maka akan berdampak pada meningkatnya minat belajar sebesar 0,198 satuan. Kemudian apabila variabel keterampilan memberi penguatan $\left(\mathrm{X}_{2}\right)$ ditingkatkan satu satuan maka akan berdampak pada meningkatnya minat belajar sebesar 0,390 satuan. Adapun konstanta sebesar 63,549 menyatakan bahwa jika tidak ada hubungan variabel bebas $\left(\mathrm{X}_{1}\right.$ dan $\left.\mathrm{X}_{2}\right)$, maka nilai minat belajar adalah 63,549.

Selanjutnya untuk dapat mengetahui apakah variabel bebas $\left(\mathrm{X}_{1}\right.$ dan $\left.\mathrm{X}_{2}\right)$ secara simultan berhubungan terhadap variabel terikat $(Y)$, maka dilakukan uji serempak (uji F) dan untuk menjelaskan pengaruh masing-masing variabel bebas terhadap variabel terikat, maka dilakukan uji parsial (uji t). Untuk membuktikan hipotesis 3, maka digunakan uji F. Dari hasil analisis program SPSS dengan taraf signifikansi $\alpha=0,05$

diketahui $\mathrm{F}_{\text {hitung }}=6,787$ sedangkan $\mathrm{F}_{\text {tabel }(2,47 ; 0,05)}=3,20$. Dengan demikian $\mathrm{F}_{\text {hitung }}>\mathrm{F}$ 
tabel $(6,787>3,20)$ demikian juga taraf signifikansi lebih kecil dari $\alpha=0,05(0,003<$ $0,05)$.

Dengan demikian dapat disimpulkan bahwa kedua variabel bebas yang terdiri dari komunikasi interpersonal $\left(\mathrm{X}_{1}\right)$, keterampilan memberi penguatan $\left(\mathrm{X}_{2}\right)$ secara simultan berhubungan secara signifikan dengan minat belajar pada Pendidikan Agama Islam. Maka, dapat diambil kesimpulan bahwa hipotesis kerja $\left(\mathrm{H}_{2}\right)$ yang berbunyi: "komunikasi interpersonal dan keterampilan memberi penguatan secara simultan memiliki hubungan yang signifikan dengan minat belajar pada Pendidikan Agama Islam di kelas VII SMP Negeri 1 Pungging", dapat diterima atau terbukti kebenarannya, sedangkan hipotesis null (Ho) ditolak. Besarnya kontribusi seluruh variabel $\left(\mathrm{X}_{1}\right.$ dan $\left.\mathrm{X}_{2}\right)$ dengan minat belajar $(\mathrm{Y})$ ditunjukkan oleh angka $\mathrm{R}^{2}$ (koefisien determinasi) sebesar 0,224 atau 22,4\% selebihnya 77,6\% berhubungan oleh variabel atau faktor lainnya yang belum diteliti. Hubungan antara variabel-variabel di atas dapat dirangkum sebagaimana tabel berikut:

\section{Hubungan Komunikasi Interpersonal $\left(\mathbf{X}_{1}\right)$ Dan Keterampilan Memberi}

Penguatan $\left(\mathrm{X}_{2}\right)$ Dengan Minat Belajar ( $\mathrm{Y}$ )

\begin{tabular}{|c|c|c|c|c|c|c|}
\hline Korelasi & $\mathbf{R}$ & $\begin{array}{c}\mathbf{R} \\
\text { Square }\end{array}$ & Persamaan Regresi & $\begin{array}{c}\text { Harga } \\
\mathbf{F}\end{array}$ & $\begin{array}{c}\text { Sig. (2 tailed) } \\
\boldsymbol{\alpha}=\mathbf{0 , 0 5}\end{array}$ & Interpretasi \\
\hline $\mathrm{X}_{1}-\mathrm{Y}$ & 0,289 & 0,083 & $\hat{Y}=81,247+0,279$ & 4,371 & 0,042 & Signifikan \\
\hline $\mathrm{X}_{2}-\mathrm{Y}$ & 0,429 & 0,184 & $\hat{Y}=75,848+0,435$ & 10,817 & 0,002 & Signifikan \\
\hline $\mathrm{X}_{1,2}-\mathrm{Y}$ & 0,473 & 0,224 & $\hat{Y}=63,549+0,198+0,390$ & 6,787 & 0,003 & Signifikan \\
\hline
\end{tabular}

\section{PEMBAHASAN PENELITIAN}

\section{Hubungan antara Komunikasi Interpersonal Guru Pendidikan Agama}

\section{Islam dengan Minat Belajar Pendidikan Agama Islam}

Bagi guru sangat penting untuk memiliki kemampuan komunikasi interpersonal yang baik, agar tidak mengalami kesulitan dalam mengajar. Dan juga agar terhindar dari kesalahan ketika membantu siswa dalam belajar. Sebagaimana yang diungkapkan Muhammad bahwa tujuan komunikasi interpersonal salah satunya yaitu untuk membantu dan merubah tingkah laku. ${ }^{17}$ Dan dalam hal ini yaitu untuk

${ }^{17}$ Arni Muhammad, Komunikasi Organisasi, (Jakarta: Bumi Aksara, 2005), 168. 
membantu siswa dalam belajar dan juga merubah tingkah laku siswa agar menjadi lebih baik sebagai hasil dari proses belajar tersebut. Jika guru mempunyai keahlian komunikasi interpersonal yang baik, maka komunikasi yang dilakukan dalam proses pembelajaran akan berjalan lancar. Dengan komunikasi yang baik itu akan melahirkan ketertarikan bagi peserta didik dalam menerima pelajaran. Peserta didik akan lebih memberikan perhatian yang intensif terhadap materi yang sedang diajarkan, karena proses penyampaian informasi yang baik oleh guru tersebut. Sebagaimana yang diungkapkan Safari bahwa semua itu merupakan pengukuran dari minat belajar. ${ }^{18}$

Jadi komunikasi interpersonal mempunyai hubungan dengan minat belajar. Hal ini terbukti dari hasil penelitian secara empirik yang menunjukkan bahwa $r_{\text {hitung }}$ $(0,289)$ berkorelasi positif dengan derajat hubungan rendah. $F_{\text {hitung }}\left(F_{\text {Change }}\right)=4,371$ dan $\mathrm{F}_{\text {tabel }(2,47 ; 0,05)}=3,20$ dengan $p$-value $=0,042<0,05$, sehingga koefisien komunikasi interpersonal adalah signifikan. Dari perhitungan analisis data dengan SPSS diketahui bahwa $t_{\text {hitung }}$ sebesar 2,091 sedangkan $t_{\text {tabel (0,05:47) }}$ adalah 2,011. Dengan demikian dapat dijelaskan bahwa $t_{\text {hitung }}>t_{\text {tabel }}(2,091>2,011)$ oleh karena itu Ha diterima. Ini berarti bahwa korelasi komunikasi interpersonal dengan minat belajar adalah berarti atau signifikan. Karena korelasi adalah positif, maka dapat dikatakan bahwa koefisien korelasi komunikasi interpersonal bersifat positif artinya makin tinggi komunikasi interpersonal makin tinggi pula minat belajar siswa yang dapat dilakukan.

Adapun persamaan regresi yang terbentuk dari analisis data dalam SPSS adalah: $\hat{Y}=81,247+0,279$. Dari persamaan regresi tersebut diketahui bahwa variabel bebas bertanda positif, ini berarti bahwa variabel bebas memiliki hubungan searah dengan variabel terikatnya. Artinya jika variabel komunikasi interpersonal $\left(\mathrm{X}_{1}\right)$ ditingkatkan satu satuan maka akan berdampak pada meningkatnya minat belajar sebesar 0,279 satuan. Sedangkan konstanta sebesar 81,247 menyatakan bahwa jika tidak ada hubungan variabel bebas $\left(\mathrm{X}_{1}\right)$ maka nilai komunikasi interpersonal adalah 81,247. Adapun besarnya koefisien determinasi ( $R$ Square) adalah 0,083. Ini artinya variabel komunikasi interpersonal memberikan konstribusi dengan minat belajar siswa sebesar $8,3 \%$ selebihnya $91,7 \%$ dipengaruhi variabel atau faktor lainnya yang

18Safari, Evaluasi Pembelajaran, (Jakarta: Departemen Pendidikan Nasional, 2003), 20. 
belum diteliti seperti motivasi, dorongan dari orang tua, tersedianya sarana dan prasarana, maupun keadaan lingkungan. ${ }^{19}$

Hal ini juga diperkuat dari hasil wawancara dengan waka kurikulum SMP Negeri 1 Pungging yang menyatakan bahwa guru Pendidikan Agama Islam adalah orang yang jujur, terbuka, ramah dan juga suka membantu orang lain, sehingga siswa menjadi senang ketika belajar Pendidikan Agama Islam. ${ }^{20}$

Ini berarti bahwa hubungan komunikasi interpersonal dengan minat belajar adalah berarti atau signifikan rendah. Karena korelasi adalah positif, maka dapat diambil kesimpulan bahwa komunikasi interpersonal mempunyai hubungan dengan minat belajar Pendidikan Agama Islam siswa kelas VII di SMP Negeri 1 Pungging Mojokerto, artinya tinggi rendahnya minat belajar pada materi Pendidikan Agama Islam mempunyai hubungan dengan komunikasi interpersonal.

\section{Hubungan antara Keterampilan Memberi Penguatan Guru Pendidikan Agama Islam dengan Minat Belajar Pendidikan Agama Islam}

Keterampilan memberi penguatan merupakan keterampilan memberi respon positif dengan tujuan mempertahankan dan meningkatkan perilaku tertentu. ${ }^{21}$ Penguatan diberikan pada siswa dengan tujuan utama agar frekuensi tingkah laku positif siswa dapat meningkat. Hal ini sesuai dengan teori belajar Skinner dan Suryabrata yang menyatakan bahwa tingkah laku peserta didik dapat dikondisikan dengan memberikan penguatan (reinforcement). ${ }^{22}$

Berdasarkan uraian tersebut penguatan dapat meningkatkan perilaku positif peserta didik. Salah satu perilaku positif tersebut adalah minat yang meningkat. Begitu juga menurut Danim, yang menyatakan bahwa tujuan pemberian penguatan di antaranya yaitu untuk meningkatkan perhatian dan membangkitkan motivasi siswa. Apabila perhatian yang merupakan salah satu dari pengukuran minat belajar semakin baik, maka dengan sendirinya memotivasi siswa dan minat belajarnya akan semakin baik pula. ${ }^{23}$

\footnotetext{
${ }^{19}$ Sumadi Suryabrata, Psikologi Pendidikan, (Jakarta: Raja Grafindo Persada, 2002), 14.

${ }^{20}$ Hasil wawancara pasa tanggal 9 Mei 2017dengan Bapak Drs. Gundari Yanto, M. MPd.

${ }^{21}$ Barnawi dan M. Arifin, Op. Cit., 141.

${ }^{22}$ Sumadi Suryabrata, Metodologi Penelitian, (Jakarta: Rajawali Pres, 2010), 217.

${ }^{23}$ Sudarwan Danim, Pengembangan Profesi Guru: Dari Pra-Jabatan, Induksi, ke Professional Madani, Jakarta: Prenada Media Group, 2011), 119.
} 
Jadi keterampilan memberi penguatan mempunyai hubungan dengan minat belajar. Hal ini terbukti dari hasil penelitian secara empirik yang menunjukkan bahwa $\mathrm{r}_{\text {hitung }}(0,429)$ berkorelasi positif dengan derajat hubungan agak rendah. $\mathrm{F}_{\text {hitung }}\left(\mathrm{F}_{\text {Change }}\right)$ $=10,817$ dan $\mathrm{F}_{\text {tabel }(2,47 ; 0,05)}=3,20$ dengan p-value $=0,002<0,05$. Dengan demikian koefisien korelasi ketrampilan memberi penguatan dengan minat belajar adalah signifikan. Dari hasil perhitungan analisis data dengan SPSS diketahui bahwa $t_{\text {hitung }}$ sebesar 3,289 sedangkan $t_{\text {tabel (0,05:47) }}$ adalah 2,011. Dengan demikian dapat dijelaskan bahwa $t_{\text {hitung }}>t_{\text {tabel }}(3,289>2,011)$ oleh karena itu Ha diterima. Ini berarti bahwa korelasi keterampilan memberi penguatan dengan minat belajar adalah signifikan. Karena korelasi adalah positif, maka dapat dikatakan bahwa koefisien korelasi keterampilan memberi penguatan dengan minat bersifat positif dan signifikan artinya makin tinggi keterampilan memberi penguatan makin tinggi pula minat belajar yang dapat dicapai.

Adapun persamaan regresi yang terbentuk dari analisis data dengan SPSS adalah: $\hat{Y}=75,848+0,435$. Dari persamaan regresi tersebut diketahui bahwa variabel bebas bertanda positif, ini berarti bahwa variabel bebas memiliki hubungan searah dengan variabel terikatnya. Artinya jika variabel keterampilan memberi penguatan $\left(\mathrm{X}_{2}\right)$ ditingkatkan satu satuan maka akan berdampak pada meningkatnya minat belajar 0,435 satuan. Sedangkan konstanta sebesar 75,848 menyatakan bahwa jika tidak ada hubungan variabel bebas $\left(\mathrm{X}_{2}\right)$ maka minat belajar adalah 75,848 . Adapun besarnya koefisien determinasi ( $R$ Square) adalah 0,184. Ini artinya variabel keterampilan memberi penguatan memberikan konstribusi minat belajar sebesar 18,4\% selebihnya $81,6 \%$ berhungan dengan variabel atau faktor lainnya yang belum diteliti seperti motivasi, dorongan dari orang tua, tersedianya sarana dan prasarana, maupun keadaan lingkungan. ${ }^{24}$

Hal ini juga diperkuat dari hasil wawancara dengan salah satu siswa kelas VII SMP Negeri 1 Pungging yang menyatakan bahwa ia merasa senang dan lebih giat belajar ketika guru Pendidikan Agama Islam memberikan simbol atau benda tertentu sebagai hadiah dari hasil pengerjaan tugas yang telah diberikan, ia juga mengatakan

${ }^{24}$ Sumadi Suryabrata, Op.Cit., 14. 
bahwa ia merasa senang ketika guru mendekati dan mendampinginya ketika dalam mengerjakan tugas. ${ }^{25}$

Ini berarti bahwa hubungan keterampilan memberi penguatan dengan minat belajar adalah berarti atau signifikan agak rendah. Karena korelasi adalah positif, maka dapat diambil kesimpulan bahwa keterampilan memberi penguatan mempunyai hubungan dengan minat belajar Pendidikan Agama Islam siswa kelas VII di SMP Negeri 1 Pungging Mojokerto, artinya tinggi rendahnya minat belajar pada materi Pendidikan Agama Islam mempunyai hubungan dengan keterampilan memberi penguatan.

\section{Hubungan antara Komunikasi Interpersonal Guru Pendidikan Agama Islam dan Keterampilan Memberi Penguatan Guru Pendidikan Agama Islam dengan Minat Belajar Pendidikan Agama Islam}

Komunikasi interpersonal dan keterampilan memberikan penguatan memiliki hubungan. Guru yang memiliki kemampuan komunikasi interpersonal baik, akan dapat menyampaikan materi pelajaran dengan tepat sesuai dengan tujuan belajar. Jika kemampuan komunikasi interpersonal dipadukan dengan keterampilan guru memberi penguatan dalam kegiatan belajar mengajar, maka akan meningkatkan perhatian dan ketertarikan siswa serta keterlibatan siswa dalam belajar, yang mana semua itu merupakan pengukuran dari minat belajar. ${ }^{26}$ Dari hasil penelitian secara empirik dapat diketahui bahwa nilai signifikansi antara komunikasi interpersonal dengan keterampilan memberi penguatam adalah $0,129>0,05$ yang berarti tidak terdapat korelasi yang signifikan. Berdasarkan hasil analisis data dengan program SPSS, maka dapat menghasilkan persamaan regresi sebagai berikut:

$$
\hat{Y}=63,549+0,198+0,390
$$

Dari persamaan tersebut dapat dijelaskan bahwa koefisien regresi linier berganda dari kedua variabel bebas bertanda positif, ini memiliki arti bahwa kedua variabel bebas tersebut $\left(\mathrm{X}_{1}\right.$ dan $\left.\mathrm{X}_{2}\right)$ memiliki hubungan searah dengan variabel terikatnya. Artinya jika variabel komunikasi interpersonal $\left(\mathrm{X}_{1}\right)$ ditingkatkan satu satuan maka akan berdampak pada meningkatnya minat belajar sebesar 0,198 satuan.

\footnotetext{
${ }^{25}$ Hasil wawancara pada tanggal 9 Mei 2017 engan Marta Della F. salah satu siswa kelas VII A SMP Negeri 1 Pungging.

${ }^{26}$ Safari, Op.Cit., 20.
} 
Kemudian apabila variabel keterampilan memberi penguatan $\left(\mathrm{X}_{2}\right)$ ditingkatkan satu satuan maka akan berdampak pada meningkatnya minat belajar sebesar 0,390 satuan. Adapun konstanta sebesar 63,549 menyatakan bahwa jika tidak ada hubungan variabel bebas $\left(\mathrm{X}_{1}\right.$ dan $\left.\mathrm{X}_{2}\right)$, maka nilai minat belajar adalah 63,549.

Taraf signifikansi $\alpha=0,05$. Dari hasil analisis data dengan SPSS diketahui $\mathrm{F}$ hitung $=6,787$ sedangkan $\mathrm{F}_{\text {tabel }(2,47 ; 0,05)}=3,20$. Sehingga $\quad \mathrm{F}_{\text {hitung }}>\mathrm{F}_{\text {tabel }}(6,787>3,20)$ demikian juga taraf signifikansi lebih kecil dari $\alpha=0,05(0,003<0,05)$. Dengan demikian dapat disimpulkan bahwa kedua variabel bebas yang terdiri dari komunikasi interpersonal $\left(\mathrm{X}_{1}\right)$ dan keterampilan memberi penguatan $\left(\mathrm{X}_{2}\right)$ secara simultan berhubungan secara signifikan dengan minat belajar pada Pendidikan Agama Islam. Maka, dapat diambil kesimpulan bahwa hipotesis kerja $\left(\mathrm{H}_{2}\right)$ yang berbunyi: "komunikasi interpersonal dan keterampilan memberi penguatan secara simultan memiliki hubungan yang signifikan dengan minat belajar pada Pendidikan Agama Islam di kelas VII SMP Negeri 1 Pungging", dapat diterima atau terbukti kebenarannya, sedangkan hipotesis null (Ho) ditolak. Besarnya kontribusi seluruh variabel $\left(\mathrm{X}_{1}\right.$ dan $\left.\mathrm{X}_{2}\right)$ dengan minat belajar $(\mathrm{Y})$ ditunjukkan oleh angka $\mathrm{R}^{2}$ (koefisien determinasi) pada Tabel 4.25 sebesar 0,224 atau 22,4\% selebihnya 77,6\% berhubungan oleh variabel atau faktor lainnya yang belum diteliti seperti motivasi, dorongan dari orang tua, tersedianya sarana dan prasarana, maupun keadaan lingkungan. ${ }^{27}$

Jadi, untuk mencapai tujuan pendidikan yang diharapkan, hendaknya guru perlu meningkatkan komunikasi interpersonal dan keterampilan memberi penguatan agar dapat meningkatkan minat belajar siswa. Karena minat menimbulkan kepuasan. Seorang anak cenderung untuk mengulang-ulang tindakan-tindakan yang didasari oleh minat dan minat ini dapat bertahan selama hidupnya. Dengan demikian, minat belajar merupakan faktor yang sangat penting dalam keberhasilan belajar siswa.

Di samping itu juga diperkuat dari hasil wawancara dengan guru Pendidikan Agama Islam. Beliau menagatakan bahwa ketika siswa diperlakukan secara sama dan diajak menarik kesimpulan bersama-sama di akhir pelajaran, siswa menjadi lebih memperhatikan dan tertarik untuk mengungkapkan pendapatnya. Selain itu ketika

${ }^{27}$ Sumadi Suryabrata, Op.Cit., 14. 
diberikan penguatan dengan kata-kata pujian atau kalimat dukungan dari hasil jawabannya tersebut, akhirnya siswa menjadi lebih antusias dalam belajar. ${ }^{28}$

Dengan demikian menunjukkan bahwa terdapat hubungan antara komunikasi interpersonal dan keterampilan memberi penguatan dengan minat belajar.

\section{SIMPULAN DAN SARAN}

Berdasarkan kajian analisis yang disesuaikan dengan pembahasan artikel ini, maka dapat diambil sebuah kongklusi bahwa terdapat hubungan positif signifikan yang rendah antara komunikasi interpersonal guru Pendidikan Agama Islam dengan minat belajar Pendidikan Agama Islam siswa kelas VII di SMP Negeri 1 Pungging Mojokerto. Hal ini dapat dilihat dari hasil perhitungan yang diperoleh yaitu nilai koefisien korelasi $\left(\mathrm{r}_{\mathrm{xy}}\right)$ antara komunikasi interpersonal dengan minat belajar adalah 0,289 yang artinya berkorelasi positif dengan derajat hubungan rendah. $\mathrm{F}_{\text {hitung }}\left(\mathrm{F}_{\text {Change }}\right)$ $=4,371$ dan $\mathrm{F}_{\text {tabel }(2,47,0,05)}=3,20$ dengan p-value $=0,042<0,05$ sehingga koefisien komunikasi interpersonal adalah signifikan. Dan $t_{\text {hitung }}$ sebesar 2,091 sedangkan $t_{\text {tabel }}$ $(0,05: 47)$ adalah 2,011. Dengan demikian $t_{\text {hitung }}>t_{\text {tabel }}(2,091>2,011)$ oleh karena itu Ha diterima. Terdapat hubungan positif signifikan yang agak rendah antara keterampilan memberi penguatan guru Pendidikan Agama Islam dengan minat belajar Pendidikan Agama Islam siswa kelas VII di SMP Negeri 1 Punnging Mojokerto. Hal ini dapat dilihat dari hasil perhitungan yang diperoleh yaitu nilai koefisien korelasi $\left(\mathrm{r}_{\mathrm{xy}}\right)$ antara keterampilan memberi penguatan dengan minat belajar adalah 0,429 yang artinya berkorelasi positif dengan derajat hubungan agak rendah. $F_{\text {hitung }}\left(F_{\text {Change }}\right)=10,817$ dan $\mathrm{F}_{\text {tabel }(2,47 ; 0,05)}=3,20$ dengan p-value $=0,002<0,05$ sehingga koefisien korelasi ketrampilan memberi penguatan dengan minat belajar adalah signifikan. Dan $t_{\text {hitung }}$ sebesar 3,289 sedangkan $t_{\text {tabel (0,05:47) }}$ adalah 2,011. Dengan demikian $t_{\text {hitung }}>t_{\text {tabel }}$ (3,289> 2,011) oleh karena itu Ha diterima. Komunikasi interpersonal guru Pendidikan Agama Islam dan keterampilan memberi penguatan guru Pendidikan Agama Islam secara simultan memiliki hubungan positif signifikan yang agak rendah dengan minat belajar Pendidikan Agama Islam siswa kelas VII di SMP Negeri 1 Pungging. Hal ini dapat dilihat dari hasil perhitungan yang diperoleh yaitu nilai

\footnotetext{
${ }^{28}$ Hasil wawancara pada tanggal 9 Mei 2017 dengan Ibu Rupiyanah, S. Ag.
} 
koefisien korelasi $\left(\mathrm{R}_{\mathrm{x} 1 \mathrm{x} 2 \mathrm{y}}\right)$ antara komunikasi interpersonal dan keterampilan memberi penguatan dengan minat belajar adalah 0,473 yang artinya berkorelasi positif dengan derajat hubungan agak rendah. $F_{\text {hitung }}=6,787$ sedangkan $F_{\text {tabel }(2,47 ; 0,05)}=3,20$. Sehingga $\mathrm{F}_{\text {hitung }}>\mathrm{F}_{\text {tabel }}(6,787>3,20)$ demikian juga taraf signifikansi lebih kecil dari $\alpha=0,05$ $(0,003<0,05)$ oleh karena itu Ha diterima.

Sebagai pendidik terutama dalam Pendidikan Agama Islam diharapkan semakin meningkatkan kemampuan komunikasi interpersonal dan keterampilannya dalam memberikan penguatan untuk meningkatkan minat belajar siswa. Dan bagi siswa diharapkan adanya peningkatan kesadaran tentang pentingnya minat belajar, karena minat belajar merupakan faktor yang sangat penting dalam keberhasilan belajar siswa. Bagi pihak sekolah harus menciptakan lingkungan yang mendukung untuk terciptanya kondisi yang dapat meningkatkan minat belajar siswa seperti meningkatkan ekstrakurikuler yang ada dan meningkatkan kelengkapan sarana dan prasarana dalam belajar. Karena masih banyak kekurangan yang disebabkan oleh keterbatasan waktu ataupun referensi, sehingga diharapkan peneliti selanjutnya mengadakan penelitian lanjutan dengan menggunakan variabel lain yang secara teoritis berhubungan dengan minat belajar.

\section{DAFTAR PUSTAKA}

Aqib, Zainal. 2007. Membangun Profesionalisme Guru dan Pengawas Sekolah. Bandung: Yrama Widya.

Barnawi dan M. Arifin. 2015. Micro Teaching. Yogyakarta: Ar-Ruzz Media.

Danim, Sudarwan. 2011. Pengembangan Profesi Guru: Dari Pra-Jabatan, Induksi, Ke Professional Madani. Jakarta: Prenada Media Group.

Hamid, Akib. 2009. Statistika Dasar. Jakarta: UT.

Khairani, Makmun. 2013. Psikologi Belajar. Yogyakarta: Aswaja Pressindo.

Muhammad, Arni. 2005. Komunikasi Organisasi. Jakarta: Bumi Aksara.

Mulyana, Deddy. 2000. Ilmu Komunikasi: Suatu Pengantar. Bandung: Remaja Rosdakarya.

Munandar, S. C. Utami. 1985. Mengembangkan Bakat dan Kreativitas Anak Sekolah: Petunjuk bagi Para Guru dan Orang Tua. Jakarta: Gramedia Widiasarana Indonesia. 
Prastyo, H. 2017. Pemberdayaan Pesantren: membangun Generasi Islami melalui Pembinaan Keterampilan Berbahasa Asing, Al-Murabbi: Jurnal Studi Kependidikan dan Keislaman, 4(1):17-28

Rakhmat, Jalaluddin. 2012. Psikologi Komunikasi. Bandung: Remaja Rosdakarya.

Safari. 2003. Evaluasi Pembelajaran. Jakarta: Departemen Pendidikan Nasional.

Supriadie, Didi, dan Deni Darmawan. 2012. Komunikasi Pembelajaran. Bandung: PT. Remaja Rosdakarya.

Suranto. 2011. Komunikasi Interpersonal. Yogyakarta: Graha Ilmu.

Suryabrata, Sumadi. 2002. Psikologi Pendidikan. Jakarta: Raja Grafindo Persada.

_.2010. Metodologi Penelitian. Jakarta: Rajawali Press.

19 Palapa: Jurnal Studi Keislaman dan Ilmu Pendidikan 